\title{
EFFECTIVENESS AND SAFETY DIFFERENCES OF ISOXSUPRINE AND NIFEDIPINE AS TOCOLYTICS IN THE RISK OF PRETERM LABOR
}

\author{
Nur Oktavia $^{1}$, Yulistiani ${ }^{1}$, Unedo H Markus ${ }^{2}$, Hendriette Irene Mamo ${ }^{2}$ \\ ${ }^{1}$ Department of Clinical Pharmacy, Faculty of Pharmacy, Universitas Airlangga, Surabaya, ${ }^{2}$ Department of Obstetrics \\ and Gynecology, Prof. Dr. WZ. Johannes Hospital, Kupang
}

\begin{abstract}
ABSTRAK
Persalinan prematur merupakan penyebab tingginya angka kesakitan dan kematian perinatal. Penggunaan tokolitik adalah salah satu upaya penanganan ancaman persalinan prematur. Tokolitik yang banyak digunakan di Indonesia adalah isoksuprin dan nifedipin. Tujuan dari penelitian ini adalah untuk melihat perbedaan efektivitas dan keamanan isoksuprin sebagai tokolitik pada ancaman persalinan prematur. Penelitian ini adalah penelitian observasional berupa case study yang dilakukan secara terperinci dan mendalam terhadap pasien yang terdiagnosa partus prematurus imminens. Sebagai simpulan, terdapat perbedaan keefektivan dan keamanan dari isoksuprin dan nifedipin sebagai tokolitik pada ancaman persalinan prematur. (FMI 2017;53:242-246)
\end{abstract}

Kata kunci: Ancaman persalinan prematur; efektivitas; keamanan; tokolitik

\begin{abstract}
Premature labor is a cause of high rates of perinatal morbidity and mortality. The use of tocolytics is one of the efforts to handle the risk of preterm labor. Tocolytics which are widely used in Indonesia is isoxsuprine and nifedipine. The purpose of this study was to identify the difference of effectiveness and safety of isoxsuprine as tocolytics in the risk of preterm labor. This was an observational study in the form of a case study that was done in detail and depth to the patients who were diagnosed as imminent preterm labor. In conclusion, there were differences in the effectiveness and safety of isoxsuprine and nifedipine as tocolytics in the risk of preterm labor. (FMI 2017;53:242-246)
\end{abstract}

Keywords: The risk of preterm labor; effectiveness; safety; tocolytics

Correspondence: Nur Oktavia, Department of Clinical Pharmacy, Faculty of Pharmacy, Universitas Airlangga, Jalan Dharmawangsa Dalam, Surabaya 60286, Indonesia. Email: oktavia.nur65@gmail.com

\section{INTRODUCTION}

Spontaneous preterm labor is one of the causes of high rates in infant morbidity and mortality (van Geijin et al 2005). Preterm labor is a major problem for family as well as social environment and is an important issue in the field of human reproduction, both in developed and developing countries, such as Indonesia (Suspimantari 2013). In 2010, around the world, there was an estimation of $11.1 \%$ of living labors were preterm labors. This trend increases in some countries, such as Malawi, Zimbabwe and Indonesia. The appropriate management of the risk of preterm labor is an important step in achieving the MDG's 4th goal (Blencowe et al 2013). According to Riskesdas 2013, NTT ranked third from all provinces in Indonesia for LBW cases. The high incidence of LBW can be an indication of high incidence of preterm labor in a certain place (POGI 2011). Preterm labor can be caused by health problems in pregnant women and the fetus.

Thus, an attempt to delay the occurrence of preterm labor is necessary, one of which is the use of tocolytics.
Various drugs included in tocolytics types are betamimetic (isoxsuprine, ritodrine and terbutaline), $\mathrm{Ca}$ channel blockers (nifedipine, nicardipine), antiprostaglandin (indomethacin, ketorolac, sulindac), magnesium sulfate (Jusuf 2008), oxytocin receptor antagonists (atosiban), as well as nitric oxide donor drugs (Simhan \& Caritis 2007).

The purpose of tocolytic drug use is to reduce episodes of uterine contractions (acute contractions) and to maintain uterine contractions after acute episodes of contraction (Agudelo et al 2011), so preterm labor can be inhibited. Therefore, the provision of tocolytic therapy has an important role in the efforts to improve the outcome of preterm birth (Haas et al 2012). The administration of tocolytics is expected to reduce fetal morbidity and mortality due to prematurity.

Currently, isoxsuprine is used as a tocolytic drug in the management of preterm labor problems in Obstetric and Gynecology Department of Prof. Dr. WZ Johannes Hospital, Kupang. Isoxsuprine has working effect on beta 1 or beta 2 receptors. This class causes peripheral vasodi- 
lation by directly effecting the smooth muscle of blood vessels, especially in skeletal muscle with little effect on blood flow in the skin and uterine relaxation (Pradyuman \& Mekhla 2014). However, the effectiveness of this drug is limited in value because it affects cardiovascular system significantly, and the success rate in delaying preterm labor is relatively small. The side effects on cardiovascular are the most common ones in the use of isoxsuprine as tocolytic (Yogol et al 2009).

Another drug that can be used as tocolytic is nifedipine. Nifedipine is one of the drugs of dihydropyridine on CCB class which has widespread use in the management of vascular disorders in nonpregnant individuals. Nifedipine has evolved in its use, not only as an antihypertensive but has also been used as one of the tocolytic drugs because of its effect on the smooth muscle of the uterus so it can be used for the prevention of premature birth. Its use for this purpose has been done for the past 30 years and several studies have been conducted on women with normal blood pressure (Yamasato et al 2015). Nifedipine is proved to cause relaxation of smooth muscle in the uterus. In vitro, several studies have demonstrated the ability of nifedipine to inhibit myometrial contractions in pregnant and nonpregnant women.

There are several controversies that arise related to the ability of isoxsuprine and nifedipine as one of tocolytic drugs. Therefore, this study was conducted on the effectiveness and safety differences of nifedipine and isoxsuprine as tocolytics in inhibiting the risk of preterm labor by observing several parameters: delayed labor (48 hours), bishop score, contraction, and side effects (dizziness, nausea, vomiting and tachycardia and hypotension). This study was expected to provide another alternative for the selection of tocolytics that can be used to prevent the risk of preterm labor, can provide input to the hospital's standard operating procedure in handling the risk of preterm labor, and is expected to be used as an effort in improving the quality of pharmaceutical services in Prof. Dr. WZ. Johannes Hospital.

\section{MATERIALS AND METHODS}

This was an observational study in the form of an intensive, detailed and in-depth case study of patients diagnosed with imminent preterm labor according to the inclusion criteria and tocolytic therapy. This study was conducted in Obstetrics and Gynecology Department of Prof. Dr. WZ. Johannes Hospital, Kupang. The samples of this study were all patients diagnosed with imminent preterm labor and according to the inclusion criteria for 3 months observation from April 5 to July 5, 2016. The inclusion criteria in this study were $28-36$ weeks' gestation, single pregnancy, normotension, imminent preterm labor, and agreed to participate in this study. The exclusion criteria were indications for termination of pregnancy, PRM, chorioamnionitis/intra uterine infection, bleeding, preeclampsia/eclampsia, IUFD, heart disease, kidney disease, thyroid gland disorder, DM, gemelly pregnancy and hydroamnion. Whereas, the dropout criteria were membrane rupture during the study and patients discharged at their own request before delivery occurred.

Variables used in the study were $10 \mathrm{mg}$ isoxsuprine, 10 mg nifedipine, therapy effectiveness (delayed delivery $=2 \times 24$ hours, bishop score and contraction) and safety (effect on blood pressure, side effects such as tachycardia, dizziness, nausea and vomiting). The data obtained were tabulated and analyzed descriptively, while the blood pressure change data were analyzed statistically with $\mathrm{p}$ value $<0.05$.

\section{RESULTS}

Sample studies of differences in the effectiveness and safety of isoxsuprine and nifedipine as tocolytics in the risk of preterm labor were 17 patients admitted to the hospital during the period of April 5 to July 5, 2016 and had met the inclusion criteria. The characteristic profile of patients in this study can be seen in Table 1 .

Data in Table 1 show that all patients in the study are at 28-36 weeks' gestation with $88 \%$ of patients in the 20 35 age range or included in the healthy reproductive group. There were $24 \%$ of the patients who also sufferred from anemia, in which anemia is a health problem which can be one of the triggering factors of preterm labor. It is because the decrease in hemoglobin concentration in anemic patients can lead to tissue hypoxia which will then produce cortisol and prostaglandin (Sudoyo 2009). The high cortisol and prostaglandin will cause uterine contractions that result in the risk of preterm labor. Data on the effectiveness of tocolytic use based on labor delay can be seen in Table 2.

The effectiveness of tocolytic based on bishop score and contraction can only be obtained at the beginning of the observation, while at the end, it was not done with the consideration to keep the patients' comfort. In this study, all patients had Bishop score of 0-5. Seventy six percent of premature birth occurred in patients with Bishop score $=5$ (Jusuf 2008). In this study, there were 2 patients who failed to maintain the pregnancy within 48 hours after administration of isoxsuprine, so it can be said that the effectiveness of tocolytic users in patients with Bishop score $<5$ was $87.5 \%$. 
Table 1. Patients' characteristic profile

\begin{tabular}{|c|c|c|}
\hline Characteristics & $\begin{array}{c}\text { Patients } \\
(\mathrm{n}=17)\end{array}$ & $\begin{array}{l}\text { Percentage } \\
(\%)\end{array}$ \\
\hline \multicolumn{3}{|l|}{ Age (years old) } \\
\hline$<20$ & 2 & 12 \\
\hline $20-35$ & 15 & 88 \\
\hline$>35$ & 0 & 0 \\
\hline \multicolumn{3}{|l|}{ Age of pregnancy } \\
\hline $28-32$ & 8 & 47 \\
\hline $33-36$ & 9 & 53 \\
\hline \multicolumn{3}{|l|}{ Parity } \\
\hline $\begin{array}{l}\text { Parity at risk } \\
\text { Parity not at risk }\end{array}$ & 7 & 41 \\
\hline \multicolumn{3}{|l|}{$\begin{array}{l}\text { History of abortion/ } \\
\text { partus prematurus }\end{array}$} \\
\hline Yes & 2 & 12 \\
\hline No & 15 & 88 \\
\hline \multicolumn{3}{|l|}{ Anemia } \\
\hline $\begin{array}{l}\text { Yes } \\
\text { No }\end{array}$ & 4 & 24 \\
\hline \multicolumn{3}{|l|}{ Working } \\
\hline Yes & 4 & 35 \\
\hline No & 13 & 65 \\
\hline
\end{tabular}

Table 2. Effectivity of tocolytics based on labor delay

\begin{tabular}{ccc}
\hline Tocolytic & \multicolumn{2}{c}{ Number of Patients (\%) } \\
\cline { 2 - 3 } Effectiveness & $<2 \times 24$ (hours) & $\geq 2 \times 24$ (hours) \\
\hline Isoxsuprine & & $13(86.67)$ \\
Successful & 0 & 0 \\
Failed & $2(13.33)$ & \\
Nifedipine & & $2(100)$ \\
Successful & 0 & 0 \\
Failed & 0 & \\
\hline
\end{tabular}

Note: Total of patients with isoxsuprine was 15 , and nifedipine 2

Isoxsuprine and nifedipine have working mechanism that affects the smooth muscle of blood vessels, so it can affect the patients' blood pressure. The use of tocolytics related to blood pressure changes can be seen in Table 3. Table 3 shows that there was no significant change of patients' blood pressure before and after receiving therapy with $\mathrm{p}$ value $>0.5$.

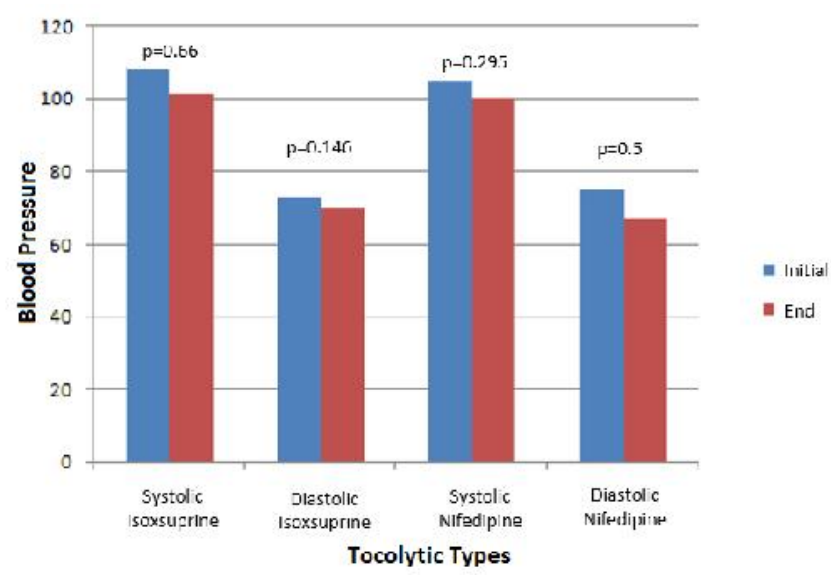

Fig. 1. Changes in blood pressure in initial and end of observation.

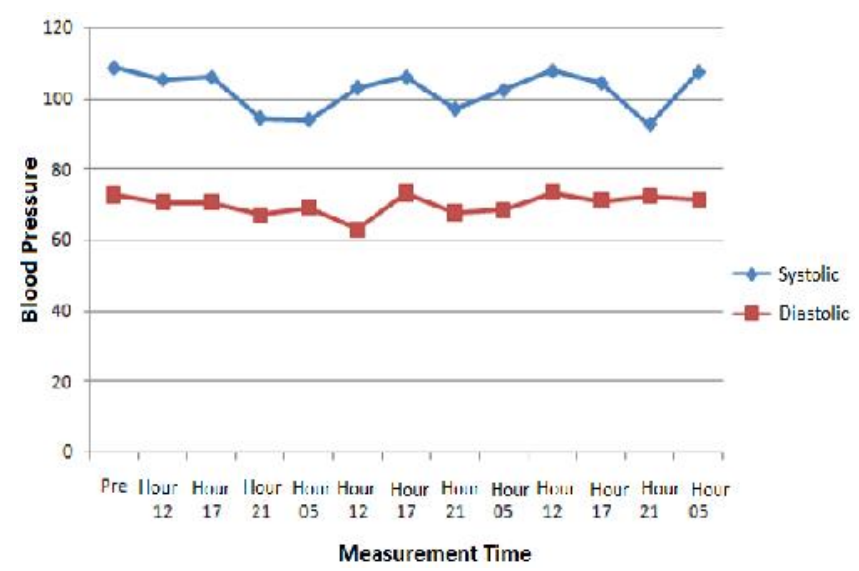

Fig. 2. Changes in blood pressure with isoxsuprine therapy.

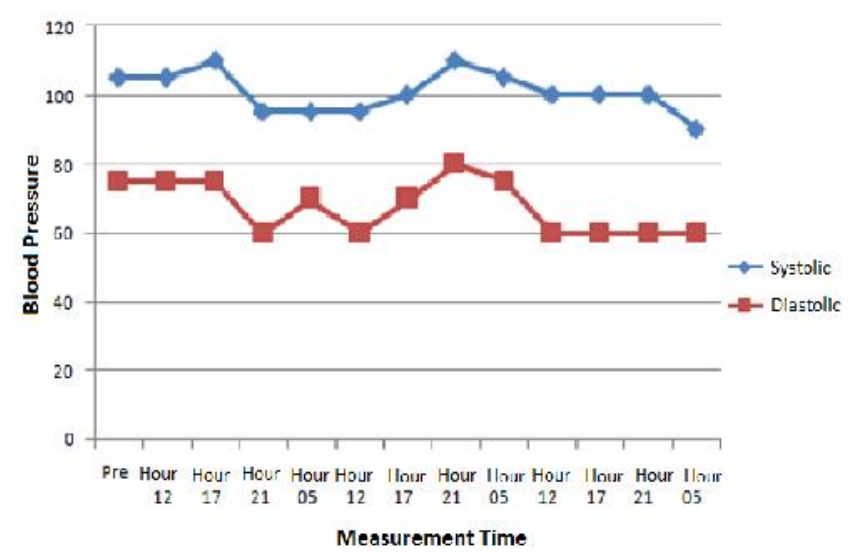

Fig. 3. Changes in blood pressure with nifedipine therapy. 
Data and statistics showed that the use of nifedipin or isoxsuprine did not affect blood pressure in patients with normotension. The safety of tocolytic use was seen from the presence or absence of arising side effects. Out of 15 patients who received isoxsuprine therapy, one patient had shortness and pulmonary oedema, while one patient complained of a rash on skin and resulting in tachycardia after use. Whereas, in patients receiving nifedipine therapy, one patient complained dizziness after receiving the initial dose of nifedipine as shown in Table 4.

The incidence of pulmonary edema in the use of isoxsuprine may be because it had antidiuretic effects. Its use can reduce urine output, increase central nervous system pressure, decrease oncotic pressure and cause capillary immersion. The management of pulmonary edema can be done by reducing per minute density and duration of infusion for less than 48 hours. The route of intravenous administration of isoxsuprine is also a factor in the incidence of more serious adverse events than the use of nifedipine orally. This is because if drugs are given intravenously, the availability of drugs in the blood is immediate, so that the possibility of toxic effects become higher. Therefore, the use of nifedipine is preferred and selected to be the first-line tocolytic (POGI 2011, RCOG 2011). The use of nifedipine has several advantages over isoxsuprine in addition to its oral use. In terms of price, nifedipine has cost effectiveness. It is easy to obtain and less side effects. The $\mathrm{Ca}$ channel blocker group other than nifedipine which also has tocolytic effect is nicardipine. However, similar to isoxsuprine, the route of nicardipine admi-nistration is also intravenous, and it also has high price. Nicardipine is also rarely selected as tocolytics. Where-as, amlodipine, as a member of the ca channel blocker group, does not have tocolytic effect. Amlodipine is a long acting ca channel blocker which has slow onset but long working period, while the handling of preterm labor risks requires drugs with immediate onset.

The safety and effectiveness of isoxsuprine and nifedipine is shown in Table 5. Isoxsuprine is capable of delaying labor $2 \times 24$ hours of $86.67 \%$ with a change in blood pressure of $6.5 \%$ and takes time as long as 71.33 \pm 33 hours to eliminate contraction. Whereas, nifedipine takes time to eliminate contraction as long as 44.5 \pm 5 hours with $4.3 \%$ reduction in blood pressure and successfully delays labor $2 \times 24$ hours by $100 \%$.

\section{CONCLUSION}

There were differences in the ability of isoxsuprine and nifedipine in labor delay for $2 \times 24$ hours, the length of time required to stop contractions since the onset of initial contractions, in the percentage of the decrease in blood pressure, and in the side effects.

Table 3. Blood pressure changes in initial and end of observation

\begin{tabular}{|c|c|c|c|c|c|c|c|c|}
\hline \multirow[b]{2}{*}{$\begin{array}{c}\text { Blood } \\
\text { Pressure }\end{array}$} & \multicolumn{4}{|c|}{ Isoxsuprine } & \multicolumn{4}{|c|}{ Nifedipine } \\
\hline & Initial & End & $\delta(\%)$ & $\begin{array}{c}\text { Value } \\
\text { (p) }\end{array}$ & Initial & End & $\delta(\%)$ & $\begin{array}{c}\text { Value } \\
\text { (p) }\end{array}$ \\
\hline Systolic & $\begin{array}{c}108.7 \pm \\
9.9\end{array}$ & $\begin{array}{c}101.65 \pm \\
10.2\end{array}$ & 6.48 & 0.66 & $\begin{array}{c}105 \pm \\
7.1\end{array}$ & $\begin{array}{l}100.4 \\
\pm 6.3\end{array}$ & 4.38 & 0.295 \\
\hline Diastolic & $\begin{array}{c}72.7 \pm \\
7.9 \\
\end{array}$ & $\begin{array}{c}69.9 \pm \\
8.7 \\
\end{array}$ & 3.85 & 0.146 & $\begin{array}{c}75 \pm \\
7.1\end{array}$ & $\begin{array}{c}67.1 \pm \\
5.3\end{array}$ & 10.53 & 0.5 \\
\hline
\end{tabular}

Table 4. Side effects of tocolytic use

\begin{tabular}{|c|c|c|c|}
\hline \multirow{2}{*}{ Side Effects } & \multicolumn{2}{|c|}{ Number of the Patients } & \multirow{2}{*}{ The Mechanism of Side Effect Occurrence } \\
\hline & Isoxsuprine & Nifedipine & \\
\hline Hypotension & 0 & 0 & - Isoksuprin causes peripheral vasodilation and \\
\hline Nausea/vomiting & 0 & 0 & redistributes blood flow to organs and increa- \\
\hline Dizziness & 0 & 1 & ses cardiac output; the onset of a rash is one \\
\hline $\begin{array}{l}\text { Pulmonary edema }+ \\
\text { shortness of breath }\end{array}$ & 1 & 0 & $\begin{array}{l}\text { of hypersensitivity reactions } \\
\text { - Nifedipine causes side effects, such as head- }\end{array}$ \\
\hline Tachycardia + rash & 1 & 0 & $\begin{array}{l}\text { ache, which is the result of temporary hypo- } \\
\text { tension due to the use of loading dose }\end{array}$ \\
\hline Total & 2 & 1 & \\
\hline
\end{tabular}


Table 5. Effectiveness and safety of tocolytic use

\begin{tabular}{|c|c|c|c|c|}
\hline \multirow[b]{2}{*}{ Tocolytic Types } & \multicolumn{2}{|c|}{ Effectivity } & \multicolumn{2}{|c|}{ Safety } \\
\hline & $\begin{array}{c}\Sigma \text { Successful Patients } \\
(\%)\end{array}$ & $\begin{array}{l}\text { Tocolytic Onset of } \\
\text { Action } \\
\text { (Hour) }\end{array}$ & $\downarrow$ Blood Pressure & $\Sigma$ ESO \\
\hline Isoxsuprine & $\begin{array}{l}86.67 \% \\
(n=15)\end{array}$ & $71.33 \pm 33$ & $6.5 \%$ & $\begin{array}{l}\text { 2, i.e. pulmonary edema } \\
+ \text { spasms and tachycar- } \\
\text { dia + rash }\end{array}$ \\
\hline Nifedipine & $\begin{array}{l}100 \% \\
(\mathrm{n}=2)\end{array}$ & $44.5 \pm 5$ & $4.3 \%$ & 1, i.e. dizziness \\
\hline
\end{tabular}

\section{REFERENCES}

Agudelo AC, Romero R, Kusnovic JP (2011). Nifedipin in the management of preterm labor: a systematic review and metaanalysis. American Journal of Obstetrics \& Gynecology 204, p134.e1-20

Blencowe H, Cousens S, Chou D, et al (2013). Born too soon: the global epidemiology of 15 million preterm births. Reproductive Health 10, S2

Haas DM, Caldwell DM, Kirkpatrick PR, McIntosh JJ, Welton NJ (2012). Tocolytic therapy for preterm delivery: systematic review and network meta-analysis. British Medical Journal 345, e6226

Jusuf J (2008). Efektivitas dan efek samping ketorolac sebagai tokolitik pada ancaman persalinan prematur, tinjauan perbandingan dengan nifedipin. Semarang, Universitas Dipenogoro

POGI (2011). Panduan pengelolaan persalinan preterm nasional. Bandung, Himpunan Kedokteran Fetomaternal POGI

Pradyuman V, Mekhla G (2014). a comparative study of two tocolytic agents for inhibition of preterm labour. Gujarat Medical Jurnal 69
Simhan HN, Caritis SN (2007). Prevention of preterm delivery. The New England Journal of Medicine 357, 477-87

Sudoyo AW (2009). Buku ajar penyakit ilmu dalam. 5th ed. Jakarta, Interna Publishing

Suspimantari C (2014). Faktor-faktor resiko prematuritas yang berpengaruh terhadap luaran maternal dan perinatal berdasarkan usia kehamilan. Semarang, Universitas Dipenogoro

RCOG (2011). Tocolysis for women in preterm labour. Green-top Guidline No. 1b. Royal College of Obstetricians and Gynaecologist. February

van Geijn HP, Lenglet JE, Bolte AC (2005). Nifedipine trials: effectiveness and safety aspects. BJOG: an International Journal of Obstetrics \& Gynaecology 112, 79-83

Yamasato K, Burlingame J, Kaneshiro Bliss (2015). Hemodynamic effects of nifedipin tocolysis. The Journal of Obstetrics and Gynaecology Research 41, 17-22

Yogol NS, Shakya R, Thapa P (2009). Ritodrine and isoxsuprine in management of preterm labor. Journal of Nepal Medical Association 48, 265-8 